\title{
Marketing Strategy for Indonesian for Speakers of Other Language Unit (Unit BIPA): A Case Study in Unit BIPA Universitas Muria Kudus
}

\author{
Eko Widianto ${ }^{1}$, Ahmad Hariyadi $^{2}$, Dwi Novaria Misidawati ${ }^{3}$, Siti Aniqoh Shofwani ${ }^{4}$, Ana \\ Putri Nastiti $^{5}$ \\ \{eko.widianto@umk.ac.id ${ }^{1}$, ahmadhariyadi86@gmail.com², vava_caemImoet@yahoo.com ${ }^{3}$, \\ aniqoh_2014@gmail.com ${ }^{4}$, putri25ananta@gmail.com ${ }^{5}$ \} \\ ${ }^{1}$ Universitas Muria Kudus, Indonesia \\ ${ }^{2}$ IKIP PGRI Bojonegoro, Indonesia \\ ${ }^{3}$ IAIN Pekalongan, Indonesia \\ ${ }^{4,5}$ STIE Semarang, Indonesia
}

\begin{abstract}
Indonesian language is prepared to be an international language in a future. One of the way to reach it, a government raise Indonesian language through Indonesian for speakers of other language learning (BIPA). As international recognition, Universitas Muria Kudus serve Indonesian course for foreigners through Unit BIPA. Thus, marketing strategies became the first key to exist the unit. This study aimed to describe 1) marketing strategies for Unit BIPA Universitas Muria Kudus, 2) the opportunities and challanges of Unit BIPA's existence, 3) the benefits of marketing strategy for Unit BIPA Universitas Muria Kudus. A case study was used as a methodology approach, as well as marketing strategies as a theoritical approach. The data were collected by interview and observation. Therefore, this study describe a big role of marketing strategies for Unit BIPA as language and culture diplomatic way in Indonesia.
\end{abstract}

Keywords: marketing strategy, bipa, language and culture diplomatic

\section{Introduction}

Marketing strategies have many elements in life. This knowledge is not only used in the economic field. As one of the disciplines, marketing science is also used in various aspects, one of which is teaching. This knowledge is used as an external support for education. Marketing knowledge is used as a promotional strategy and supporting the existence of a product. For this reason, BIPA teaching which in one hand is a commodity, also needs to use marketing strategies for promotion and existence.

Understanding marketing contains a broader understanding than just sales and advertising. Tjiptono ${ }^{[1]}$ (2002:7) provides the definition of marketing as a social and managerial process for individuals or groups to obtain needs and desires through the creation, coloring, and exchange of all things of value with other people or groups.

In this case, BIPA or Indonesian for foreign speakers has several dimensions (Suhardijanto ${ }^{[2]}$ 2016; Wurianto ${ }^{[3]}$ 2016; and Damaianti ${ }^{[4]}$ 2016). These dimensions are BIPA as a science, as an industry, as a profession, and as a means of diplomacy. For this reason, the mandate of BIPA is not just in the classroom as teaching Indonesian for foreign citizens. However, BIPA has 
become a complex space that includes a vision of introducing Indonesian culture on the international cooperation.

Opinions of several experts related to the BIPA sector indicate that the future of Indonesian has a bright face. BIPA is not only seen as a science. However, BIPA is also seen as a promising industry. The industry can also be developed personally and institutionally. BIPA can be designed into a personal industry through private courses offered to foreign nationals who will learn Indonesian with various objectives. Meanwhile, BIPA as an institutional industry can be developed in institutions, including universities.

This research is used as a case study description of the implementation of marketing strategies at Unit BIPA Universitas Muria Kudus. The marketing strategy is carried out for the promotion of programs and branding. In addition, it is also described opportunities and challenges of the existence of Unit BIPA Universitas Muria Kudus through a marketing strategy. In addition, also known the benefits of marketing strategies for Unit BIPA Universitas Muria Kudus.

\section{Methodology}

This research was designed using the case study method. A study by observe the case of the process in research object. For this reason, in this study, researchers also act directly as practitioners. In addition, the data is presented with a qualitative descriptive method with interpretation of non-formal data.

\section{Discussion}

\section{1) Marketing Strategies for Unit BIPA Universitas Muria Kudus}

The marketing strategies of Unit BIPA Universitas Muria Kudus are carried out in various interesting ways. The steps taken vary from the classical normative to the modern way. The method is as follows.

a. Direct promotion to users (Door to Door Promotion)

Promotion is done by direct bidding to users. In this case, Unit BIPA Universitas Muria Kudus promotion team offers programs to clients. This method has a high degree of accuracy. That is, the client or user can be interested in participating in BIPA learning program if it matches the program offered. Another consideration is the price in accordance with user expectations.

b. Social media branding

In addition to direct offers, Unit BIPA Universitas Muria Kudus also encompasses users or clients through social media. It is used as a form of promotion widely. Unlike the previous method which tends to the selling process, this method is more directed to branding. Therefore, through social media the Unit BIPA Universitas Muria Kudus displays program profiles, teachers, and facilities in an attractive and modern way.

c. Community networking

Relationships with teacher associations also help in the promotion process. Through APPBIPA, Unit BIPA Universitas Muria Kudus can carry out program promotions. Discussions that are held in professional associations can add to BIPA's network. Therefore, various programs are also obtained from professional associations. 


\section{2) The Opportunities and Challanges of Unit BIPA's Existence}

In the marketing process, there are opportunities and challenges. Opportunities that exist in the marketing process of Unit BIPA Universitas Muria Kudus are as follows.

a. The number of foreign workers continues to increase in Central Java

The Office of Manpower and Transmigration (Disnakertrans) of Central Java Province noted, Foreign Workers (TKA) working in Central Java jumped sharply. Of the 2,119 TKA at the end of 2017, now in 2018 it reaches 14,148 TKA $^{[5]}$. This has become a great opportunity for BIPA program to promote the Indonesian language and culture.

b. Manpower Agency rules that require foreign workers to have an Indonesian language certificate

Central Java Governor Regulation number 560/016667 in Year 2015 Regarding Controlling the Use of Foreign Workers ${ }^{[6]}$ explains that all TKA in Central Java are required to have Indonesian language skills. Therefore, TKA must be facilitated by Indonesian language training. This is also in line with the mandate of Law (Undang-Undang nomor 24 Tahun 2009) concerning the improvement of the function of Indonesian as an international language.

c. BIPA is increasingly recognized by the world community

Various language and cultural diplomacy programs have been carried out by the government through the Ministry of Education and Culture. This increases the image and popularity of Indonesian in the international arena. For this reason, this condition provides a good opportunity for BIPA program.

Meanwhile, the challenges faced in the marketing process of Unit BIPA Universitas Muria Kudus are as follows.

a. The number institutions are increasingly offering BIPA teaching services

BIPA teaching institutions are increasingly mushrooming. In Central Java, there are many campuses that have started pioneering BIPA institutions. In addition, there are also many private tutors and cannot be dammed by their development and movement. Therefore, this is the biggest challenge for the existence of Unit BIPA Universitas Muria Kudus.

b. Many private BIPA teachers (Non-Institutions)

Like BIPA institutions which are increasingly blooming, private tutors are also born massively from various linguistic disciplines. Starting from Indonesian scholars, to foreign language graduates. Therefore, there are not a few foreign citizens who choose to study privately with a freelance teacher compared to studying at institutions such as universities.

c. User requests for short-term learning

Another challenge arises in terms of the learner. Most, especially foreign workers, choose short-term programs. This benefits them more in terms of time and cost. However, from the aspect of mastery of language skills is certainly very lacking. Data in the field also shows that most learning programs taken by TKA are matriculation classes. This class only presents one day of learning. Next, TKA tests to get an Indonesian language training certificate. 


\section{3) The Benefits of Marketing Strategy for Unit BIPA Universitas Muria Kudus.}

There are several benefits gained through this marketing strategy. Unit BIPA Universitas Muria Kudus receives practical benefits in the form of stronger BIPA exposure in the community. In addition, Unit BIPA Universitas Muria Kudus can also develop various programs according to user interests. For example Unit BIPA Universitas Muria Kudus has organized a BIPA program for tourism. The program is a number of participants from various countries, both Asia, Africa, and Europe. This program provides insight into Holy tourism to foreign citizens. In addition, the main benefit of a good marketing strategy is the existence of Unit BIPA Universitas Muria Kudus in the midst of global competition.

\section{Conclussion}

The marketing strategy is carried out for the promotion of programs and branding. The marketing strategies of Unit BIPA Universitas Muria Kudus are carried out in various interesting ways. Despite having many opportunities, there are also challenges that must be addressed professionally. For that, it needs a mature and well-established strategy in the promotion and marketing process. Thus, short-term and long-term benefits can be achieved optimally.

\section{Refernces}

[1] Tjiptono,Fandy. 2002. Strategi Pemasaran. Yogyakarta: Penerbit Andi

[2] Suhardijanto, Totok. 2016. "Tantangan dan Peluang Pengembangan BIPA di Masa Mendatang: Penguatan Dimensi-Dimensi BIPA". Prosiding SEMAR BIPA 2016. Universitas Negeri Semarang. Volume I. Hal. 10-17.

[3] Wurianto, Arif Budi. 2016. "Pengembangan dan Pembelajaran BIPA Berbasis Lintas Budaya". Prosiding SEMAR BIPA 2016. Universitas Negeri Semarang. Volume I. Hal. 18-25.

[4] Damaianti, Vismaia S. 2016. "Internalisasi Wawasan Kebangsaan dalam Menguatkan Citra Diri Bangsa Para Pengajar BIPA". Prosiding SEMAR BIPA 2016. Universitas Negeri Semarang. Volume I. Hal. 26-29.

[5] Rizqi, Alif Nazzala. 2018. Jumlah Tenaga Kerja Asing Jateng Melonjak 700\%. https://semarang.bisnis.com/read/20180802/535/823626/jumlah-tenaga-kerja-asingjateng-melonjak-700.

[6] Peraturan Gubernur Jawa Tengah nomor 560/016667 Tahun 2015 Perihal Pengendalian Penggunaan Tenaga Kerja Asing. 